\title{
PENDAMPINGAN MEMBUAT STRATEGI PENGUKURAN EVALUASI KEGIATAN PADA ORGANISASI RUANG PUBLIK TERPADU RAMAH ANAK (RPTRA)
}

\author{
Michael Christian $^{1)^{*}}$ dan Glisina Dwinoor Rembulan ${ }^{2)}$ \\ ${ }^{1)}$ Manajemen/Fakultas Ilmu Sosial dan Humaniora, Universitas Bunda Mulia \\ ${ }^{2)}$ Teknik Industri/Fakultas Teknologi dan Desain, Universitas Bunda Mulia
}

Diterima 12 Agustus 2019 / Disetujui 14 September 2019

\begin{abstract}
As a place or area of meeting as well as interacting through activities that can be supported in it, the Child Friendly Integrated Public Space (RPTRA) can be explained to have a variety of quite complex work programs that are expected to be implemented well. There are at least 3 (three) aspects of the function of the RPTRA work program that must be implemented, namely services to children, services to the community and disaster services. This study aims to assist the RPTRA management in evaluating which work programs are the top priority that must be carried out. This research involved RPTRA administrators in the Sunter area, North Jakarta. Evaluation assistance is carried out when implementing community service activities with the same topic. The results of this study found that in the aspect of service to children, the performance of making RPTRA as a playground and forum forum for children became a priority indicator of all the existing indicators. Furthermore, in the aspect of service to the community explained that the performance to make RPTRA as a place for complaints of children and women became the main point. In the aspect of disaster services, it is explained that the RPTRA can be used as a container for disaster prevention at any time (for example: floods, fires, and so on). With the limitations of existing research methods, researchers expect further research to explore aspects of other important indicators that are considered by RPTRA administrators in carrying out work programs.
\end{abstract}

Keywords: RPTRA, work program, DKI Jakarta, evaluation

\begin{abstract}
ABSTRAK
Sebagai tempat atau area bertemu sekaligus berinteraksi melalui kegiatan yang dapat didukung di dalamnya, Ruang Publik Terpadu Ramah Anak (RPTRA) dapat dijelaskan memiliki ragam program kerja yang cukup kompleks yang diharapkan dapat terlaksana dengan baik. Paling tidak terdapat 3 (tiga) aspek fungsi dari program kerja RPTRA yang harus dilaksanakan yaitu layanan kepada anak, layanan kepada masyarakat dan layanan kebencanaan. Penelitian ini bertujuan untuk mendampingi para pengurus RPTRA dalam melakukan evaluasi program kerja mana yang menjadi prioritas utama yang harus dilakukan. Penelitian ini melibatkan para pengurus RPTRA di area Sunter, Jakarta Utara. Pendampingan evaluasi dilakukan pada saat pelaksanaan kegiatan pengabdian kepada masyarakat dengan topik yang sama. Hasil dari penelitian ini diperoleh bahwa pada aspek layanan kepada anak, kinerja untuk menjadikan RPTRA sebagai tempat bermain dan wadah forum bagi anak menjadi indikator prioritas dari keseluruhan indikator yang ada. Selanjutnya pada aspek layanan kepada masyarakat menjelaskan bahwa kinerja untuk menjadikan RPTRA sebagai tempat pengaduan anak dan perempuan menjadi poin utama. Pada aspek layanan kebencanaan menjelaskan bahwa RPTRA sewaktu-waktu dapat dijadikan sebagai wadah penampungan dari bencana (misal: banjir, kebakaran, dan sebagainya). Dengan keterbatasan metode penelitian yang ada, peneliti mengharapkan penelitian berikutnya dapat menggali aspek indikator penting lainnya yang menjadi pertimbangan para pengurus RPTRA dalam menjalankan program kerja.
\end{abstract}

Kata Kunci: RPTRA, program kerja, DKI Jakarta, evaluasi 


\section{PENDAHULUAN}

Ruang Publik Terpadu Ramah Anak (RPTRA) dapat dijelaskan sebagai tempat atau area bertemu sekaligus berinteraksi melalui kegiatan yang dapat didukung di dalamnya (Permanasari \& Lientino, 2018). Kepala Dinas Perumahan Rakyat dan Kawasan Permukiman DKI Jakarta menyatakan bahwa pada tahun 2018 jumlah RPTRA di Jakarta mencapai 290 titik sebaran (Carina, 2018). Bedasarkan sumber tesebut, jumlah ini sudah menandakan target Pemerintah Propinsi DKI Jakarta dalam hal pengadaan RPTRA sudah mencapai target. Pada dasarnya RPTRA digunakan untuk menjadi area interaksi bagi publik khususnya saluran minat bakat anak-anak. Bagi anak-anak kegiatan seperti bermain dapat membentuk tumbuh kembang anak (Rodger \& Ziviani, 2006) dan membentuk persahabatan (Shonkoff \& Phillips, 2000). Keberhasilan fungsi RPTRA ini dapat didukung dari tersedianya fasilitas pendukung program kegiatan tersebut. Standar fasilitas yang mencakup sisi keselamatan, keamanan, kesehatan, dan kenyamanan sebenarnya sudah dijelaskan dalam Peraturan Gubernur No. 196 Tahun 2015 dan Peraturan No. 213 Tahun 2016 (jdih.jakarta.go.id, 2015; 2016) walaupun belum jelasnya teknis aturan standar yang mengikat di dalamnya. Sejalan dengan hal tersebut, dalam area RPTRA aspek aksesibilitas menjadi poin sangat baik walaupun aspek keamanan dan kenyamanan masih menjadi catatan (Samsudin \& Artiningrum, 2017) yang harus terus ditingkatkan. Dalam pasal 6 dijelaskan juga fungsi RPTRA yaitu sebagai area taman terbuka untuk publik, tempat bermain dan tumbuh kembang anak, bentuk sarana dan prasarana kemitraan dalam pemenuhan hak anak dan kota layak anak, ruang hijau dan area penyerapan air tanah, wadah pengembangan kegiatan sosial, media usaha peningkatan pendapatan keluarga, pusat informasi/konsultasi keluarga, halaman keluarga yang asri teratur indah dan nyaman, dan sistem informasi manajemen.

Poin-poin ini memperjelas bahwa RPTRA memiliki cakupan fungsional yang melibatkan aspek perhatian terhadap anak, keluarga, masyarakat sekitar dan lingkungan. Terkait hal di atas, salah satu fenomena yang juga sering ditemui di kotakota besar adalah kurang tersedianya taman kota dan taman untuk bermain khususnya bagi anak (Baskara, 2011). Dalam kaitannya dengan area ramah anak, pemerintah telah membuat program Kota Layak Anak (KLA) yang bekerja sama dengan pihak swasta. Hal ini menjelaskan bahwa pemerintah turut mendukung program ruang hijau publik ramah anak dengan menyediakan tidak hanya areanya saja namun sampai kepada fasilitas terkait di dalamnya. Hal mendasar yang menjadi karakter ruang publik seperti ini yaitu terdapatnya daerah berumput juga jalur hijau (Li \& Li, 2017) yang bila sebenarnya dilihat lebih jauh lagi merupakan tantangan yang tidak mudah bagi kota-kota besar seperti Jakarta. Penyediaan standar peralatan dan perlengkapan yang ada di RPTRA dapat mendukung keberhasilan program pengurus. Oleh karena itu, evaluasi berjangka perlu dilakukan untuk menjaga standar ruang publik terpadu ramah anak. Beberapa penelitian juga telah mencoba untuk menjelaskan evaluasi-evaluasi yang dilakukan pada RPTRA di Jakarta.

Samsudin \& Artiningrum (2017) dalam penelitiannya di RPTRA Griya Tipar Cakung, Jakarta Timur melakukan evaluasi pada mutu secara fisik dan non fisik. Evaluasi ini dilakukan dengan cara membandingkan indikator-indikator yang digunakan dengan menggunakan observasi dan kuesioner dimana sub-variabel yang digunakan yaitu Keselamatan, Kesehatan, Keamanan, Kenyamanan, Daya Tarik, dan Aksesibilitas. Hasil perbandingan yang

\footnotetext{
$1^{*}$ Korespondensi Penulis:

Email: michaelchristianid@gmail.com
} 
diperoleh bahwa faktor Keselamatan, Kesehatan, dan Daya Tarik memiliki kesamaan hasil analisia baik secara observasi maupun secara umpan balik dengan kuesioner. Namun beberapa faktor seperti Keamanan, Kenyamanan dan Aksesibilitas memiliki perbedaan hasil. Pada observasi, ketiga faktor yang berbeda tersebut menjelaskan bahwa faktor Keamanan dan Kenyamanan dinilai kurang baik dan faktor aksesibilitas dinilai baik. Pada hasil umpan balik melaluli kusioner diperoleh hasil bahwa Keamanaan dinilai baik, Kenyamanan dinilai sangat baik, dan aksesibilitas dinilai sangat baik. Hasil ini menjelaskan bahwa terdapatnya gap antara standar yang seharusnya tersedia dengan fasilitas yang ada yang dinilai sudah baik dari persepsi pengunjung. Sebagai salah satu bentuk peningkatan kinerja pemerintah DKI melalui ketersediaan layanan publik terpadu ramah anak, standar memang sebaiknya terus diperhatikan dan dijaga keberadaaan dan aspek fungsionalnya. Dengan demikian, hal ini dapat memberikan edukasi kepada pengunjung akan standar yang harus tersedia sesuai dengan standar kualitas yang digunakan.

Evaluasi kinerja pada RPTRA juga pernah dilakukan oleh Nurhasbi \& Ernawati (2019). Pada penelitiannya di RPTRA Kalijodo di Jakarta Barat menggunakan aspek-aspek pengukuran yaitu keselamatan, kesehatan, keamanan, kenyamanan, daya tarik, aksesibilitas dan kelengkapan/kualitas fasilitas. Penelitian ini menjelaskan bahwa RPTRA di lokasi ini masih belum mampu memuaskan pengunjung. Hal ini disebabkan karena keseluruhan aspek masih belum memiliki dinilai baik dan cnderung masih buruh di dua aspek yaitu keselamatan dan kenyamanan. Berdasarkan hasil penelitian ini dapat dijelaskan bahwa evaluasi kinerja RPTRA di lokasi ini kurang berhasil apabila dinilai dari faktor ketersediaan lokasi fisik dan kelengkapan fasilitas yang ada di dalamnya.

Putra, Radnawati, Syahadat, Putra, \& Thoifur (2018) dalam penelitiannya menggunakan observasi, wawancara, dan studi literatur dengan statistik deskriptif yang melibatkan faktor-faktor yaitu lingkungan, daya dukung, tampilan, vegetasi, sosial, dan lanskap. Hasil penelitian ini menjelaskan bahwa daya dukung sudah cukup, jenis dan cara vegetasi sudah sesuai dan mutu secara tampilan masih dapat ditingkatkan. Namun demikian masih terdapat aspek-aspek yang masih butuh penanganan khusus dan peningkatan untuk perbaikan seperti aspek pembagian area/ruang yang masih belum jelas, sirkulasi dalam tapak belum maksimal, gelanggang terbuka pada tapak tidak sesuai standar dan material bermain untuk anak sudah mengalami kerusakan sehingga dapat membahayakan anak.

Penelitian evaluasi pemanfaatan Rusunawa Tambora yang dilakukan oleh Suteja, Ratnaningrum, \& Anggraini (2018) menjelaskan bahwa sebagai area yang mengalami peremajaan, tempat ini mengalami peningkatan dari segi sarana dan prasarana yang dapat mendukung aktivitas belajar dan bermain untuk anak. Di sisi lain, tetap masih membutuhkan pembenahan berkelanjutan. Aspek-aspek yang masih memerlukan pembenahan diantaranya luas taman bermaian untuk anak yang kurang sesuai standar dan kualitas material alat bermain anak terlihat sudah mengalami kerusakan.

Berdasarkan penjelasan penelitianpenelitian di atas dapat menjelaskan bahwa pengukuran evaluasi RPTRA dilakukan dengan cara menilai aspek fisik yang mencakup sarana dan prasarana area bersosialisasi dan bermain bagi anak. Padahal, faktor utama yang penting juga yang perlu dinilai adalah keberhasilan dalam melaksanakan seluruh program kerja kepengurusan suatu RPTRA. Berdasarkan fenomena tersebut, penelitian ini bertujuan untuk menganalisis evaluasi pengukuran kinerja kepengurusan RPTRA.

Identifikasi masalah yang terdapat dalam penelitian ini yaitu evaluasi kinerja RPTRA masih didominasi pada pengukuran 
sarana dan prasarana yang tersedia. Hal ini juga termasuk pada keterjagaan atau perawatan pada sarana dan prasarana yang ada. Perbandingan secara standar pada ruang publik dan RPTRA lainnya dipandang menjadi tidak adil dikarenakan RPTRA yang ada memiliki pendanaan yang berbeda. Selain itu juga penggunaan kinerja sebagai indikator evaluasi suatu RPTRA tidak jarang diabaikan karena indikator ini sering dipandang sebagai indikator untuk penilaian suatu organisasi, walaupun sebenarnya RPTRA itu sendiri dapat dinyatakan sebagai bentuk satu organisasi.

Penelitian ini bertujuan untuk menganalisis evaluasi kinerja beberapa RPTRA sekitaran area Sunter, Jakarta Utara. Selanjutnya manfaat penelitian ini secara konsep teoritis adalah diharapkan dapat memberikan kontribusi terhadap penggunaan teori evaluasi organisasi khususnya pada organisasi nirlaba. Hal ini dapat memberikan pengembanganpengembangan konsep teori organisasi. Secara konsep penelitian, hasil ini diharapkan dapat melengkapi penelitianpenelitian sebelumnya yang membahas mengenai pengukuran kinerja RPTRA.

Tabel 1. Pengembangan Instrumen

\begin{tabular}{|c|c|c|}
\hline \multirow{2}{*}{ Aspek } & \multicolumn{2}{|c|}{ Indikator } \\
\hline & No. & Deskripsi \\
\hline \multirow{7}{*}{$\begin{array}{l}\text { Layanan } \\
\text { Kepada Anak }\end{array}$} & 1 & $\begin{array}{l}\text { Pusat Informasi Dan } \\
\text { Konsultasi (Pik) }\end{array}$ \\
\hline & 2 & $\begin{array}{l}\text { Kegiatan Pos Pelayanan } \\
\text { Terpadu }\end{array}$ \\
\hline & 3 & $\begin{array}{l}\text { Perpustakaan Ramah } \\
\text { Anak }\end{array}$ \\
\hline & 4 & $\begin{array}{l}\text { Tempat Berolah Raga } \\
\text { Ramah Anak }\end{array}$ \\
\hline & 5 & Tempat Bermain Anak \\
\hline & 6 & Kegiatan Kreatif Anak \\
\hline & 7 & Kegiatan Forum Anak \\
\hline \multirow{6}{*}{$\begin{array}{l}\text { Layanan } \\
\text { Kepada } \\
\text { Masyarakat }\end{array}$} & 1 & $\begin{array}{lll}\text { Kegiatan } & 10 & \text { Program } \\
\text { PKK } & & \\
\end{array}$ \\
\hline & 2 & $\begin{array}{lll}\text { PKK } & \text { Mart } & \text { Sarana } \\
\end{array}$ \\
\hline & 3 & $\begin{array}{ll}\text { Peringatan Hari Besar } \\
\text { Nasional }\end{array}$ \\
\hline & 4 & Hajatan Masyarakat \\
\hline & 5 & $\begin{array}{l}\text { Kegiatan Olah Raga } \\
\text { Masyarakat }\end{array}$ \\
\hline & 6 & $\begin{array}{l}\text { Kegiatan Kesenian Dan } \\
\text { Kebudayaan Masyarakat }\end{array}$ \\
\hline
\end{tabular}

\section{METODE PENELITIAN}

\section{Subjek Penelitian}

Subjek pada penelitian ini yaitu para pengurus RPTRA di sekitaran area Sunter, Jakarta Utara. Penelitian ini dilaksanakan bersamaan dengan kegiatan Pengabdian Kepada Masyarakat pada tanggal 10 Juli 2019 yang bertempat di RPTRA Sunter Jaya Berseri, Jakarta Utara. Oleh karena itu, judul penelitian ini pada kegiatannya disebut dengan kegiatan pendampingan. Kegiatan tersebut dihadiri 15 orang pengurus RPTRA di sekitar area Sunter, Jakarta Utara sehingga memudahkan untuk dilakukan pengukuran berupa evaluasi kinerja kegiatan pengurus.

\section{Pengembangan Instrumen}

Aspek yang digunakan untuk melakukan evaluasi dalam penelitian ini diadaptasi dari Mungkasa (2017) yang menggunakan aspek layanan kepada anak, layanan kepada masyarakat, dan layanan kebencanaan. Aspek-aspek evaluasi yang digunakan dalam penelitian ini dijelaskan pada tabel 1 berikut:

\begin{tabular}{lll}
\hline & 7 & \multicolumn{2}{l}{$\begin{array}{l}\text { Kegiatan Pelatihan Dan } \\
\text { Sosialiasi Untuk } \\
\text { Masyarakat }\end{array}$} \\
\cline { 2 - 3 } & 8 & $\begin{array}{l}\text { Kegiatan Lanjut Usia } \\
\text { (Lansia) }\end{array}$ \\
\cline { 2 - 3 } & 9 & $\begin{array}{l}\text { Kegiatan Pelayanan } \\
\text { Kesehatan Dan KB }\end{array}$ \\
\cline { 2 - 3 } & 10 & $\begin{array}{l}\text { Pengaduan Kekerasan } \\
\text { Perempuan Dan Anak }\end{array}$ \\
\cline { 2 - 3 } $\begin{array}{l}\text { Layanan } \\
\text { kebencanaan }\end{array}$ & 11 & Perpustakaan \\
\hline & 1 & $\begin{array}{l}\text { Laktasi/Menyusui Penampungan } \\
\text { Sementara Bagi Korban } \\
\text { Bencana }\end{array}$ \\
\hline
\end{tabular}

Sumber: diadaptasi dari Mungkasa (2017)

\section{Teknik Analisis Data/Uji Statistik}

Penelitian ini menggunakan metode kuantitatif dengan statistik deskriptif. Instrumen yang digunakan adalah kuesioner yang dibagikan kepada para responden yang merupakan pengurus RPTRA yang hadir pada kegiatan Pengabdian Kepada Masyarakat tersebut. Dengan menggunakan 
SPSS 25.0 untuk analisis data, pengukuran dilakukan dengan menanyakan program kerja yang terkait dengan indikator di atas dengan skala pengukuran ada (terlaksana) dan tidak ada (tidak terlaksana). Selanjutnya dari hasil ini, akan dibuat analisis dan simpulan pada indikator program kerja yang ada.

Tabel 2. Hasil Aspek Layanan Kepada Anak

\begin{tabular}{|c|c|c|c|c|c|c|}
\hline \multirow[t]{2}{*}{ Deskripsi } & \multirow{2}{*}{$\frac{N}{\text { Statistic }}$} & \multirow{2}{*}{$\begin{array}{l}\text { Minimum } \\
\text { Statistic }\end{array}$} & \multirow{2}{*}{$\begin{array}{l}\text { Maximum } \\
\text { Statistic }\end{array}$} & \multirow{2}{*}{$\frac{\text { Sum }}{\text { Statistic }}$} & \multicolumn{2}{|l|}{ Mean } \\
\hline & & & & & Statistic & Std. Error \\
\hline LKA1 & 15 & 3 & 5 & 71 & 4,73 & 0,153 \\
\hline LKA2 & 15 & 3 & 5 & 72 & 4,80 & 0,145 \\
\hline LKA3 & 15 & 3 & 5 & 73 & 4,87 & 0,133 \\
\hline LKA4 & 15 & 4 & 5 & 73 & 4,87 & 0,091 \\
\hline LKA5 & 15 & 4 & 5 & 74 & 4,93 & 0,067 \\
\hline LKA6 & 15 & 4 & 5 & 73 & 4,87 & 0,091 \\
\hline LKA7 & 15 & 4 & 5 & 74 & 4,93 & 0,067 \\
\hline LKATOTAL & 15 & 29,00 & 35,00 & 510,00 & 34,0000 & 0,43644 \\
\hline
\end{tabular}

Sumber: peneliti, SPSS $25.0 ; n=15$

Berdasarkan hasil di atas dapat dilihat bahwa program kerja dimana RPTRA dijadikan sebagai pusat informasi dan konsultasi memiliki angka minimum sebesar 3 , angka maksimum sebesar 5 dan angka mean sebesar 4,73. Secara tidak langsung, hasil ini menjelaskan juga bahwa hampir semua pengurus RPTRA setuju bahwa indikator kinerja dalam hal menjadikan RPTRA sebagai pusat informasi dan konsultasi bagi anak harus direalisasikan dengan semaksimal mungkin. RPTRA sebagai wadah tempat berkumpul anak memungkinkan untuk secara beriringan menjadi pusat informasi dan konsultasi bagi anak. Dalam hal ini, pengurus RPTRA di sekitar area Sunter, Jakarta Utara telah menunjukkan hasil yang sangat baik secara hasil pengukuran kinerja pada indikator tersebut.

Kegiatan pos pelayanan terpadu yang memungkinkan menjadi ruang lingkup RPTRA memiliki penilaian yang cukup besar dari para pengurus RPTRA yang hadir. Indikator ini memiliki angka penilaian

\section{HASIL DAN PEMBAHASAN}

\section{Layanan Kepada Anak}

Hasil yang didapar dari aspek layanan kepada anak adalah sebagai berikut: minimum 3 dan maksimum 5 dengan ratarata sebesar 4,80. Hal ini menjelaskan bahwa pengurus RPTRA di area ini memandang pentingnya pos pelayanan terpadu dapat diintegrasikan sebagai bagian dari RPTRA. Target kegiatan yang merupakan anak-anak dinilai masih relevan untuk memaksimalkan fungsi RPTRA itu sendiri.

Dunia anak yang dekat dengan bacaan dapat menjadi pendorong bagi RPTRA agar memiliki ruang dan sumber bacaan yang memadai. Hasil pengukuran yang dilakukan secara rata-rata indikator ini memiliki angka 4,87 yang menjelaskan bahwa hal ini menjadi pertimbangan yang cukup tinggi untuk tersedia di RPTRA. Tiap harinya anak-anak akan datang dan melakukan segala aktivitas di area RPTRA dimana salah satunya sangat memungkinkan melakukan hobi anak-anak tersebut yaitu membaca. Buku-buku cerita rakyat, pejuang nasional/daerah, dan pengetahuan umum bsa menjadi referensi buku yang disediakan. Peranan swasta dan masyarakat umum diharapkan dapat memberikan konstribusi 
dalam pemenuhan kebutuhan akan buku bacaan ini.

Di dalam tubuh yang sehat terdapat jiwa yang kuat. Moto ini sering digaungkan sejak periode usia anak-anak. Oleh karena itu, RPTRA sebagai wadah tempat anak berkumpul sebaiknya memiliki unsur-unsur yang dapat mendukung kesehatan anak khususnya dalam hal berolah raga. Pada hasil evaluasi diperoleh bahwa secara ratarata menunjukkan angka sebesar 4,87 yang mengindikasikan bahwa faktor penyediaan tempat bagi anak untuk dapat berolah raga menjadi salah satu faktor yang cukup penting. Penyediaan peralatan dan ruang untuk berolahraga yang biasanya terdapat di RPTRA salah satunya yaitu area olah raga sepak bola.

Faktor lain yang memiliki penilaian yang tinggi yaitu tempat bermain anak dengan angka rata-rata 4,93. Hal ini dapat menjelaskan bahwa RPTRA sebagai wadah berkumpul anak tidak terlepas dari kegiatan bermain untuk anak. Berbagai peratalan bermain bagi anak sebaiknya dapat disediakan untuk menunjang kegiatan anak selama berada di area RPTRA. Peralatan sederhana untuk bermain bagi anak seperti perosotan, ayunan, dan kuda-kudaan dapat disediakan di area RPTRA.

Bakat anak sebaiknya diasah sejak dini. Hal ini dapat menjadikan RPTRA sebagai bagian yang dapat membentuk dan mengasah bakat anak sejak usia anak-anak. Ketersediaan ruang dan peralatan/perlengkapan untuk menggambar, mewarnai, menari, dan menyanyi dapat menjadi conoth dimana minat dan bakat anak dapat didukung untuk terus bertumbuh dan berkembang. Berdasarkan hasil pengukuran di atas, rata-rata pengurus RPTRA memberikan angka penilaian sebesar 4,87 untuk faktor ini. Hal ini menjelaskan bahwa faktor ini dinilai penting dan peranan pengurus untuk menyediakan peralatan/perlengkapan ataupun pengajar sangat perlu dipertimbangkan.

Dunia anak-anak merupakan dunia yang penuh dan ekspresi dan cerita. Anakanak sangat senang bila diajak berbicara dan menceritakan keseharian yang dilakukan seperti pengalaman liburan, pertemanan, termasuk juga mengenai keluh kesah anak. Lingkungan dan keluarga anak memiliki ceritanya tersendiri yang kadangkala membuat anak perlu untuk sekedar bercerita. Hal ini menjadi penting bagi RPTRA untuk menjadi wadah forum bagi anak. Hasil pengukuran di atas menjadikan faktor ini cukup penting dimana memberikan angka sebesar 4,93.

\section{Layanan Kepada Masyarakat}

Pada aspek layanan kepada masyarakat, hasil yang didapat dari penelitian ini sebagai berikut:

Tabel 3. Hasil Aspek Layanan Kepada Masyarakat

\begin{tabular}{lllllll} 
Deskripsi & $\boldsymbol{N}$ & Minimum & Maximum & Sum & Mean & \\
\cline { 2 - 7 } & Statistic & Statistic & Statistic & Statistic & Statistic & Std. Error \\
\hline LKM1 & 15 & 3 & 5 & 69 & 4,60 & 0,214 \\
\hline LKM2 & 15 & 3 & 5 & 65 & 4,33 & 0,211 \\
\hline LKM3 & 15 & 3 & 5 & 64 & 4,27 & 0,206 \\
\hline LKM4 & 15 & 2 & 5 & 57 & 3,80 & 0,262 \\
\hline LKM5 & 15 & 3 & 5 & 66 & 4,40 & 0,235 \\
\hline LKM6 & 15 & 3 & 5 & 66 & 4,40 & 0,214 \\
\hline LKM7 & 15 & 3 & 5 & 68 & 4,53 & 0,215 \\
\hline LKM8 & 15 & 3 & 5 & 70 & 4,67 & 0,187 \\
\hline LKM9 & 15 & 3 & 5 & 68 & 4,53 & 0,192 \\
\hline
\end{tabular}




\begin{tabular}{lllllll}
\hline LKM10 & 15 & 3 & 5 & 71 & 4,73 & 0,153 \\
\hline LKM11 & 15 & 3 & 5 & 70 & 4,67 & 0,187 \\
\hline LKM12 & 15 & 3 & 5 & 66 & 4,40 & 0,235 \\
\hline LKMTOTAL & 15 & 27,00 & 45,00 & 593,00 & 39,5333 & 1,35178 \\
\hline
\end{tabular}

Sumber: peneliti, SPSS $25.0 ; n=15$

Selain fokus pada fungsi wadah bermain dan belajar anak, RPTRA juga dapat menjadi sarana penunjanng untuk pelaksanaan program PKK. Berdasarkan hasil pengukuran, dengan angka rata-rata 4,60 pengurus RPTRA setuju bahwa RPTRA dapat disinergikan dengan pelaksanaan kegiatan PKK. Kesinambungan antara masyarakat lingkungan sekitar dapat menjadi faktor pendorong optimalisasi fungsi penggunaan RPTRA. Hasil angka tersebut merupakan angka yang cukup tinggi sehingga dapat diindikasikan menjadi salah satu faktor penting dalam aspek layanan kepada masyarakat.

RPTRA juga dapat dijadikan sebagai wadah untuk mengakomodir bakat dan hobi masyarakat setempat dalam hal membuat produk makanan ataupun non makanan yang bernilai jual. Ibu-ibu sekitar RPTRA misalnya dapat menjadikan hobi mengolah makanan untuk dijual kepada masyarakat ataupun kepada pengunjung RPTRA. Beberapa produk makanan yang sering ditemui di RPTRA seperti keripik, kue-kuean, sampai kepada sambal. Selain oitu, produk non makanan juga dapat ditemui seperti kerajinan tangan, sulaman, sarung bantal, sampai kepada pajangan dinding. Hasil pengukuran juga menunjukkan hal yang berbbanding lurus, dimana angka rata-rata umpan balik dari para pengurus RPTRA sebesar 4,33 yang mengartikan bahwa faktor ini dalam kaitannya sebagai aspek layanan kepada masyarakat harus dipertimbangkan.

Hari-hari besar nasional seperti Hari Kemerdekaan Republik Indonesia, Hari Sumpah Pemuda, Hari Kesaktian Pancasila memang tidak luput dari perayaan peringatan. Berbagai kegiatan sederhana dapat dilakukan sebagai bentuk peringatan hari besar tersebut. RPTRA sebagai bagian dari masyarakat dapat menjadi tempat yang dapat mengakomodir kegiatan-kegiatan seperti upacara, perlombaan atau menghias tempat dengan ornament tertentu. Rata-rata angka pengukuran dari para responden menunjukkan angka sebesar 4,27. Hal ini dapat menjelaskan bahwa RPTRA sebagai bagian dari masyarakat dapat turut ambil serta dalam perayaan hari-hari besar nasional yang melibatkan masyarakat setempat.

Jakarta dengan bebagai suku, agama dan ras memiliki perayaan yang khusus dan khas. Secara periodik kegiatan-kegiatan hajatan masyarakat sesuai suku, agama dan ras dapat ditemui. RPTRA dalam hal ini dapat berfungsi sebagai wadah untuk peringatan atau perayaan kegiatan tersebut. Berdasarkan hasil pengukuran dalam penelitian ini, diperoleh angka sebesar 3,80 sebagai angka rata-rata umpan balik responden yang menyatakan bahwa sebagai aspek layanan kepada masyarakat maka RPTRA memiliki andil di dalamnya untuk turut serta. Angka ini walaupun tidak tertalu tinggi di antara indikator yang lain namun mampu menjelaskan bahwa RPTRA di area penelitian ini masih memiliki nilai-nilai toleransi dan kerjasama.

Kegiatan olah raga masyarakat memang tidak dapat dipisahkan seiring dengan perayaan khususnya pada peringatan hari-hari besar. Berbagai kegiatan bersifat olah raga pun turut serta dilaksanakan dimana melibatkan masyarakat setempat. RPTRA sebagai bagian dari masyarakat juga harus memapu memberikan layanan kepada masyarakat, salah satunya dapat menjadi wadah pendukung dalam pelaksanaan kegiatan olah raga seperti sepak bola, bulu tangkis, tenis meja dan sebagainya. 
Penyediaan area tempat dan peralatan olah raga dapat disediakan oleh RPTRA. Berdasarkan hasil pengukuran di atas, angka rata-rata sebesat 4,40. Angka ini dapat menjelaskan bahwa sebagai aspek layanan kepada masyarakat, RPTRA dipandang dapat menjadi bagian dari masyarakat dalam pelaksanaan kegiatan berbentuk olah raga.

Selain kegiatan berbentuk olah raga, RPTRA dapat menjadi bagian dari masyarakat dalam pelaksanaan kegiatan berbentuk kesenian dan kebudayaan seperti musik, tarian, wayang, dan sebagainya. Anak-anak dalam hal ini dapat menjadi pengisi kegiatan dengan menunjukkan bakat yang sudah dilatih di RPTRA. Tari-tarian salah satunya yang cukup sering ditemui di masyarakat dimana anak-anak dapat terlibat di dalamnya. Hasil pengukuran yang dilakukan, angka rata-rata menunjukkan angka sebesar 4,40 yang memiliki arti bahwa faktor ini ada dan menjadi bagian dalam masyarakat dan RPTRA. Masyarakat yang ada di sekitar RPTRA yang berasal dari ragam suku, agama dan ras yang berbeda dapat menunjang terlaksananya kegiatan ini.

Bentuk pelatihan yang bekerja sama dengan pihak ketiga seperti perusahaan atau institusi pendidikan dapat menjadi sarana pendukung dalam pelaksanaan kegiatan RPTRA dan juga layanan kepada masyarakat. Pembekalan penggunaan internet sehat, penggunaan sosial media, memahami karakteristik personal dalam kepengurusan organisasi sampai kepada cara berani berkomunikasi di tempat umum merupakan beberapa topik yang dapat dijadikan bahan untuk pelaksanaan pelatihan. Masyarakat dalam hal ini dapat menjadi peserta pelatihan dimana akan mendapatkan informasi dan wawasan tambahan secara gratis oleh para narasumber yang bekerja dengan RPTRA. Berdasarkan hasil pengukuran di atas, angka rata-rata yang diperoleh sebesar 4,53 mengindikasikan bahwa indikator ini sebagai aspek layanan kepada masyarakat turut memberikan andil sebagai bagian dari program kerja pengurus RPTRA.
Area lingkungan RPTRA dapat juga digunakan sebagai tempat berkumpul dan bersosialisasinya kelompok masyarakat yang berusia lanjut (lansia). Lingkungan yang nyaman dan asri dapat menjadi sarana bagai kelompok lansia untuk saling bersosialisasi dan melakukan beberapa kegiatan misalnya berolah raga ringan, melakukan kegiatan yang menjadi hobi (menyulam, membuat kerajian tangan, dan sebagainya), sampai kepada melakukan kegiatan hobi bercanda ria seperti menyanyi dan bercengkrama. Berdasarkan hasil pengukuran di atas diperoleh angka rata-rata sebesar 4,67 yang menjelaskan bahwa tingginya angka ini memberikan indikasi bahwa RPTRA menjadi bagian penting untuk masyarakat khususnya bagi kelompok masyarakat berusia lanjut.

Pos pelayanan terpadu, pemberian makanan tambahan bernutrisi bagi anak dapat menjadi salah satu program yang dapat dilaksanakan oleh RPTRA bekerja sama dengan dinas kesehatan setempat atau kelurahan setempat. Area lingkungan yang nyaman dan ramah anak dapat menjadi titik pelaksanaan bentuk kegiatan tersebut. Dari hasil pengukuran yang dilakukan, rata-rata umpan balik dari indikator ini sebesar 4,53 yang mengartikan bahwa indikator ini pun ternyata dapat menjadi hal penting dari program kerja kepengurusan RPTRA khususnya dalam aspek layanan kepada masyarakat.

RPTRA dalam kaitannya dengan aspek layanan kepada masyarakat dapat dijadikan sebagai sentra pengaduan kekerasan pada perempuan dan anak. Hal ini diharapkan RPTRA dapat menjadi titik awal dalam hal pengaduan yang melibatkan perempuan dan khususnya anak. Pendampingan dan konseling juga perlu dipersiapkan dalam menampung korban. Berdasarkan hasik pengukuran yang dilakukan, angka rata-rata pada indikator ini menunjukkan angka sebesar 4,73 yang menjelaskan angka yang tinggi. Keadaan yang cenderung kurang aman ataupun sebagai tindakan proteksi bagi perempuan 
dan anak perlu dilakukan dan RPTRA dalam hal ini dapat menjadi fasilitas tempat pengaduan.

Tidak jauh berbeda dengan layanan kepada anak, perpustakaan dalam kaitannya sebagai aspek layanan kepada masyarakat pun dapat didukung oleh RPTRA melalui program kerja yang ada. Penyediaan sumber-sumber bacaan yang dapat menambah wawasan dan pengetahuan warga setempat menjadi faktor pendorong terdapatnya indikator ini sebagai salah satu program kerja RPTRA. Berdasarkan hasil pengukurna yang dilakukan, angka rata-rata dari indikator ini sebesar 4,67 yang juga menjelaskan bahwa fasilitas perpustakaan yang ada di RPTRA tidak hanya dapat digunakan untuk layanan kepada anak-anak saja tetapi juga dapat digunakan sebagai aspek layanan kepada masyarakat dengan fungsi yang sama.
Area aman untuk menyusui sangat penting tersedia di lingkungan masyarakat. Hal ini memungkinkan ibu-ibu bersosialisasi sambal menyusui dan bertukar pikiran mengenai menyusui. Lingkungan RPTRA dapat menjadi salah satu titik area yang aman dan nyaman bagi ibu-ibu menyusui di sekitar lingkungan. Ditambah lagi harus menemani buah hati bermain dengan teman sebayanya sambill menyusui. Berdasarkan hasil pengukuran di atas, maka dapat dijelaskan dengan angka rata-rata yang ada yaitu 4,40 maka indikator ini layak menjadi salah satu program kerja bagi pengurus RPTRA.

\section{Layanan Kebencanaan}

Pada aspek layanan kebencanaan, RPTRA dapat memberikan fungsi dan manfaat yang dijelaskan melalui tabel 4 berikut:

Tabel 4. Hasil Aspek Layanan Kebencanaan

\begin{tabular}{|c|c|c|c|c|c|c|}
\hline Deskripsi & $\begin{array}{l}N \\
\text { Statistic }\end{array}$ & $\begin{array}{l}\text { Minimum } \\
\text { Statistic }\end{array}$ & $\begin{array}{l}\text { Maximum } \\
\text { Statistic }\end{array}$ & $\begin{array}{l}\text { Sum } \\
\text { Statistic }\end{array}$ & $\begin{array}{l}\text { Mean } \\
\text { Statistic }\end{array}$ & Std. Error \\
\hline LK1 & 15 & 3 & 5 & 68 & 4,53 & 0,215 \\
\hline LKMTOTAL & 15 & 27,00 & 45,00 & 593,00 & 39,5333 & 1,35178 \\
\hline
\end{tabular}

Sumber: peneliti Sumber: peneliti, SPSS 25.0; $n=15$

Indonesia khususnya Jakarta merupakan wilayah yang cukup sering terjadi bencana. Bencana baik yang ditimbulkan secara alami (gempa, banjir, dan longsor) maupun karena faktor human error (kebakaran, kerususahan dan sebagainya), RPTRA dapat menjadi titik layanan kebencanaan yaitu sebagai pusat penampungan sementara. Berdasarkan hasil pengukuran yang dilakukan, angka rata-rata yang diperoleh sebesar 4,53 dimana angka ini tergolong cukup tinggi. Oleh karena itu dapat dijelaskan bahwa indikator ini dapat menjadi bagian dari program kerja di RPTRA.

\section{SIMPULAN}

Berdasarkan pembahasan dan analisis di atas, maka penelitian ini dapat disimpulkan sebagai berikut:
1. Pada aspek layanan kepada anak, kinerja untuk menjadikan RPTRA sebagai tempat bermain dan wadah forum bagi anak menjadi indikator prioritas dari keseluruhan indikator yang ada. Hal ini sejalan dengan fungsi utama dari RPTRA. Hal yang menjadi urutan akhir pada indikator kinerja pada aspek ini yaitu pusat informasi dan konsultasi.

2. Hasil pada aspek layanan kepada masyarakat menjelaskan bahwa kinerja untuk menjadikan RPTRA sebagai tempat pengaduan anak dan perempuan menjadi poin utama, dan indikator yang menjadi prioritas terakhir yaitu menjadikan RPTRA sebagai tempat untuk perayaan peringatan hari besar nasional. 
3. Layanan kebencanaan sebagai aspek terakhir menjelaskan bahwa indikator ini nyatanya memiliki tingkat prioritas yang cukup tinggi. Hal ini menjelaskan bahwa RPTRA sewaktu-waktu dapat dijadikan sebagai wadah penampungan dari bencana (misal: banjir, kebakaran, dan sebagainya).

\section{DAFTAR PUSTAKA}

Baskara, M. (2011). Prinsip Pengendalian Perancangan Taman Bermain Anak Di Ruang Publik. Jurnal Lanskap Indonesia, 3(1), 27-34.

Carina, J. (2018, Maret 5). Megapolitan. Retrieved September 2, 2019, From Megapolitan.Kompas.Com:

Https://Megapolitan.Kompas.Com/Rea d/2018/03/05/15405641/Kadis-

Perumahan-Sebut-Jumlah-Rptra-Di-

Jakarta-Sudah-Lampaui-Target

Jdih.Jakarta.Go.Id. (2015, Juli 7). Produk Hukum. Retrieved Agustus 5, 2019, From Https://Jdih.Jakarta.Go.Id/: Https://Jdih.Jakarta.Go.Id/Uploads/Def ault/Produkhukum/Pergub_No_196_Ta hun_2015.Pdf

Jdih.Jakarta.Go.Id. (2016, Oktober 26). Produk Hukum. Retrieved Agustus 5, 2019, From Https://Jdih.Jakarta.Go.Id: Https://Jdih.Jakarta.Go.Id/Uploads/Def ault/Produkhukum/Pergub_No.213_Ta hun_.2016_.Pdf

Li, M., \& Li, J. (2017). Analysis Of Methods Of Allocating Grass Space For The Design Of Child-Friendly Cities: A Case Study Of Changsha. Procedia Engineering, 198, $790-801$.

Mungkasa, O. M. (2017, Agustus 18). Academia.Edu. Retrieved Agustus 10, 2019, From Academia.Edu: Https://Www.Academia.Edu/34279006 /Ruang_Publik_Terpadu_Ramah_Anak
_Rptra_._Konsep_Pelaksanaan_Dan_P embelajaran?Auto=Download

Nurhasbi, M., \& Ernawati , J. (2019). Evaluasi Kinerja Ruang Publik Terpadu Ramah Anak Kalijodo Jakarta Barat. Jurnal Mahasiswa Jurusan Arsitektur, 7(1).

Permanasari, E., \& Lientino, T. (2018). Transformasi Makna Dan Fungsi Ruang Di Rptra Kalijodo Dalam Pergulatan Citra Kota Jakarta. Ruas, 16(2), 13-27.

Putra, R. T., Radnawati, D., Syahadat, R. M., Putra, P. T., \& Thoifur, D. M. (2018). Evaluasi Taman Jangkrik Sebagai Rtra Di Ciganjur, Jakarta Selatan. Seminar Nasional Sains Dan Teknologi 2018 (Pp. 1-8). Jakarta: Fakultas Teknik Universitas Muhammadiyah Jakarta.

Rodger, S., \& Ziviani, J. (2006). Occupational Therapy With Children: Understanding Children's Occupations And Enabling Participation. Oxford: WileyBlackwell.

Samsudin, \& Artiningrum, P. (2017). Evaluasi Kualitas Fisik Dan Nonfisik Pada Ruang Publik Terpadu Ramah Anak (Rptra) (Studi Kasus : Rptra Griya Tipar Cakung Jakarta Timur). Vitruvian: Jurnal Arsitektur, Bangunan, \& Lingkungan, 7(1), 31-40.

Samsudin, S., \& Artiningrum, P. (2017). Evaluasi Kualitas Fisik Dan Nonfisik Pada Ruang Publik Terpadu Ramah Anak (Rptra) (Studi Kasus : Rptra Griya Tipar Cakung Jakarta Timur). Vitruvian Jurnal Arsitektur, Bangunan, \& Lingkungan, 7(1), 31-40.

Shonkoff, J., \& Phillips, D. (2000). From Neurons To Neighborhoods: The Science Of Early Childhood Development. Washington: Dc: National Academy Press.

Suteja, M. S., Ratnaningrum, D., \& Anggraini, D. (2018). Evaluasi Ruang Publik Sebagai Ruang Sosial Yang Ramah Anak Pada Peremajaan Rusunawa Tambora. Jurnal Jurnal Muara Sains, Teknologi, Kedokteran, Dan Ilmu Kesehatan, 2(2), 469-480. 